\title{
ROZWÓJ TRANSPORTU MORSKIEGO A LUDZIE GO OBSŁUGUJĄCY I ICH KSZTAŁCENIE ZA GRANICĄ ORAZ W POLSCE
}

\author{
Łukasz Domański \\ przedsiębiorca - logistyk; były pracownik naukowy Uniwersytetu Ekonomicznego w Poznaniu
}

Od wieków ludzie uprawiali żeglugę w celu przewozu ładunków czy też zdobycia wpływów na nowych terenach. Żegluga związana jest z początkami powstania i rozwoju cywilizacji. Postęp technologiczny w transporcie morskim i śródlądowym zachodził wolno, ale w sposób ciągły i narastający, od dłubanych łodzi, do statków drewnianych a następnie o poszyciu stalowym, od napędu wiosłowego do żaglowego a potem silnikowego czy też turbinowego.

Zmieniały się rodzaje ładunków od cennej drobnicy do ładunków masowych i znowu do drobnicy, ale przewożonej w kontenerach. Zmieniały się formy własności statków towarowych od statków należących do właścicieli ładunków, czyli albo pojedynczych kupców, albo wielkich spółek kupieckich przez niezależnych armatorów dysponujących pojedynczymi statkami do wielkich przedsiębiorstw armatorskich czy też operatorów obsługujących przewozy wyczarterowanym tonażem. Zmieniało się podejście do statku. Inaczej spoglądał na statek należący do niego kupiec a zupełnie inaczej przewoźnik, którego można nazwać już od XIX wieku armatorem.

Zmieniał się też sposób kształcenia załogi a szczególnie od XIX wieku zmieniały się jej funkcje i zadania. Od nauczania przyszłych adeptów na kapitanów i oficerów statków wyłącznie przez praktykę, czyli kształcenie i naukę na statku, gdzie łączono przyswajanie wiedzy z książek pod nadzorem nauczycieli z praktyką morską, do nauczania na lądzie i połączenia jej z praktyką na morzu. Po powstaniu przedsiębiorstw armatorskich coraz ważniejszy stawał się aspekt handlowy żeglugi, czyli jej opłacalność, decydująca o rozwoju przedsiębiorstwa armatorskiego. Spowodowało to powstanie nowej gałęzi wiedzy na uczelniach handlowych, wiedzy dotyczącej zarówno ekonomicznych aspektów żeglugi, jak i zarządzania przedsiębiorstwem armatorskim i określania strategii jego rozwoju.

Obserwując rozwój żeglugi, można wydzielić trzy etapy jej rozwoju. Pierwszy trwał od początku rozwoju do 1850 roku, gdy dominowały żaglowce a więc kapitan, oficerowie i marynarze byli żeglarzami, a konstrukcja statków była do siebie zbliżona. Statki napędzane były żaglami, miały proste urządzania za- i wyładunkowe oparte częściowo na elementach omasztowania. Wewnątrz statku, w zależności od jego rozmiarów, znajdowało się wiele ładowni, z których każda miała międzypokłady, bowiem zarówno ładunki stałe, jak i płynne sztauowane były w skrzyniach różnych rozmiarów oraz beczkach, czyli baryłkach. W beczkach przewożono tak- 
że ładunki sypkie. Czas postoju w porcie był mało istotny, bowiem nigdy nie można było w miarę dokładnie określić czasu przybycia do portu przeznaczenia, jak i czasu przeznaczonego na znalezienie odpowiedniego ładunku i czasu wyjścia z tym ładunkiem w morze. W portach znajdowały się w większości nieuzbrojone w sprzęt przeładunkowy nabrzeża, poza paroma, przeznaczonymi do za- i wyładunku ciężkich i nieporęcznych ładunków.

Właścicielami statków byli przeważnie kupcy, dla których ważne było przewiezienie swoich ładunków po to, aby sprzedać je po wielokrotnie wyższej cenie w porcie przeznaczenia niż w porcie załadunku. Kupiec patrzył więc na statek z punktu widzenia ponoszonych kosztów w celu uzyskania bardzo korzystnej ceny na sprzedawanym w porcie przeznaczenia towarze. Po załadunku towaru należącego do kupca, cała odpowiedzialność za dalszą podróż spoczywała na kapitanie. To on stawał się odpowiedzialny za efekty finansowe podróży. To on w kolejnych portach szukał ładunku i negocjował stawki frachtowe. Trzymał się wytycznych kupca i nie wolno mu było wozić ładunków konkurencji. Kalkulacja stawek przewozowych dla innych, tolerowanych kupców konkurentów, stanowiła odpowiedni procent różnicy wartości, pomiędzy wartością towaru w porcie załadunku a wartością w porcie wyładunku. Wielkość tego procentowego ułamka związana była ściśle z odległością przewozu.

Innymi zadaniami kapitana było zaopatrzenie statku zarówno w żywność, jak i lekarstwa dla załogi, zaopatrzenie i wymiana zużytego ożaglowania oraz materiałów sztauerskich. Kapitan także mustrował załogę, dbał o prace konserwacyjne na statku, o odpowiednie zasztauowanie ładunku i przede wszystkim prowadził nawigację statku. Oznaczało to, że kupiec zatrudniał na lądzie jedynie księgowego, który rozliczał kapitana ze wszystkich dochodów z frachtów oraz wydatków ponoszonych na utrzymanie załogi i statku. Z tego powodu każdy kupiec starał się odpowiednio dobrać jak najlepszego kapitana i godziwie zapłacić mu za poniesiony trud.

Kształcenie oficerów odbywało się w trybie eksternistycznym. Kadeci przygotowujący się do patentów oficerskich płacili kapitanowi za naukę. Egzaminy na patent zdawano przed państwowa komisją.

Drugi etap po 1850 roku, to od samego początku był czas przyspieszonych i radykalnych zmian technologicznych w budowie i konstrukcjach statków, wyrażonych zastosowaniem stali w budowie kadłubów, co stanowiło odpowiedź na rozwijający się w postępie arytmetycznym rynek przewozów morskich, podrożenie drewna dębowego, zapotrzebowanie na statki o dużych wymiarach, a nastąpiło to w wyniku gwałtownego rozwoju handlu i przewozów ludzi pomiędzy państwami europejskimi i należącymi do nich zamorskimi koloniami.

Powstały możliwości wyodrębnienia się przedsiębiorstw armatorskich zwłaszcza w przewozach liniowych i pasażerskich, bowiem rządy poszczególnych państw zainteresowane utrzymaniem łączności z koloniami subwencjonowały w różny sposób armatorów.

Taka sytuacja sprawiła, że po raz pierwszy armator patrzył na statek jako na narzędzie przynoszące mu zysk. Dla niego statek stał się dobry lub zły wyłącznie z punktu widzenia jego efektywności oraz funkcji przewozu ładunków, do których został przeznaczony. Sama podróż statku była tylko częścią finansowego przedsięwzięcia.

Rok 1850 i lata późniejsze to okres masowego zastosowania w żegludze silnika parowego. Rozpoczęła się konkurencja żagli z maszyną parową. Zaczęły powstawać półregatowe żaglowce do przewozu ładunków wartościowych o nośności do 1000 BRT, zwane kliprami. Załogi kliprów z konieczność odpowiedniej obsługi żagli liczyły do 100 osób. Konieczne więc było 
zatrudnienie odpowiedniej osoby, która w imieniu właściciela statku, i w porozumieniu z kapitanem, dokonywałaby zakupów żywności dla załogi. Powstało stanowisko superintendenta, czyli ochmistrza, który był w rozumieniu dzisiejszym, wyspecjalizowanym kierownikiem zakupów - dbał bowiem nie tylko o zaopatrzenie załogi w żywność, ale jednocześnie wspólnie z kapitanem dokonywał zakupów elementów ożaglowania i materiałów sztauerskich oraz prowadził księgowość, to znaczy zbierał i ewidencjonował wszelkie rachunki, z których wspólnie rozliczał się z kapitanem przed armatorem. W tym samym czasie weszły do eksploatacji największe statki żaglowe, tzw. windjammery, czyli pogromcy wiatrów. Są to transoceaniczne statki towarowe, które z założenia miały konkurować z parowcami, dzięki oszczędnościom na kosztach transportu.

Pojemność Windjammerów przekraczała niekiedy 5000 BRT, a długości kadłubów dochodziły do stu kilkudziesięciu metrów. Pływały one na ściśle określonych trasach w cyklu rocznym pomiędzy Europą, Chinami, Australią i Ameryką Południowa. W tym czasie okrążały glob, wożąc węgiel, surowce mineralne (guano i rudy metali szlachetnych), tropikalne drewno i zboże. Załoga windjammerów, dzięki zastosowaniu wind parowych do podnoszenia żagli, wynosiła 50-60 osób. Windjammery rozwijając średnią prędkość ok. 15 węzłów miały przewagę nad parowcami, których osiągi w owym czasie nie przekraczały 8 węzłów, a ponadto parowce musiały być zaopatrzone w węgiel (do maszyn) i słodką wodę - kosztem ładunku. Opłacalności żaglowców sprzyjały także przepisy, czyli ulgi podatkowe w wielu krajach i wymagania od kandydatów na stopnie oficerskie odnośnie do konieczności odbywania praktyk na żaglowcach. Także dla szeregowych marynarzy wprowadzenie stalowych kadłubów statków stanowiło przełom w mentalności „przecież żelazo jest cięższe od wody i jak to może pływać?”, dodatkowo wprowadzenie maszyny parowej spowodowało, że wielu z nich ze strachu odmawiało zamustrowania na taki statek.

Rozwój technologiczny i zastosowanie kotłów wysokociśnieniowych spowodowało, że stopniowo parowce zaczęły wypierać żaglowce. Dotyczyło to zwłaszcza żeglugi liniowej, gdzie regularność kursowania statków i możliwość ułożenia terminów zawinięć i wypłynięcia do i z portów stały się niezwykle ważne. Na statku pojawiło się stanowisko I inżyniera (mechanika) i palaczy. Załoga podzieliła się na maszynę i pokład.

Przedsiębiorstwo armatorskie oprócz działu księgowości, obsadzonego przez absolwentów szkół handlowych, rozwinęło się o dział techniczny z inżynierami również kształconymi na ladzie. Zaczął się więc podział na załogę lądowa i morską.

Zakres obowiązków kapitana nadal obejmował:

- znajdowanie ładunków przy pomocy współpracujących w portach agentów,

- negocjowanie stawek frachtowych za ładunki,

- angaż załogi,

- żegluga i nawigacja statkiem,

- konserwacja i utrzymanie statku w gotowości technicznej,

- dbałość o bezpieczeństwo statku i załogi.

Do obowiązków głównego inżyniera należała eksploatacja i konserwacja silnika. Główny inżynier na statku pojawił się nie jako marynarz, lecz jako absolwent szkół technicznych, który powoli stawał się marynarzem. 
Początek wieku XX przyniósł największy przełom w żegludze, który zresztą pojawił się poza żeglugą - było to wynalezienie telegrafu kablowego z kodem systemu kropek i kresek opracowanego przez Finleya Morse'a a następnie na podstawie nadajnika Marconiego - telegrafu radiowego. Już w 1906 roku transatlantyk „Republic” nadał z morza na ląd pierwszą wiadomość. Wynalazek był tak ważny, że w ciągu paru lat cały świat został opanowany przez linie telegraficzne a także statki masowo zaczęto wyposażać w telegrafy radiowe. System telegrafów na statku i lądzie został uznany jako obowiązujący standard.

W strukturze organizacyjnej statku pojawiło się stanowisko radiotelegrafisty. Pojawienie się radiotelegrafu zmieniło w sposób zasadniczy relacje między statkiem a armatorem, zmniejszając radykalnie kompetencje i zakres obowiązków kapitana statku na rzecz armatora na lądzie, bowiem do rej pory, zwłaszcza w żegludze nieregularnej po wypłynięciu z portu macierzystego statek znikał z pola widzenia armatora i nie było sposobu komunikacji z nim, stąd o wszystkim w imieniu armatora decydował kapitan.

W żegludze regularnej armator mógł w sposób szacunkowy określić daty wpłynięcia i wypłynięcia statku z portu, a także, dzięki doświadczeniu, przewidzieć jaki ładunek i po jakich stawkach zostanie zasztauowany na statku. Rozliczenie i określenie wielkości zysku następowało jednak po przypłynięciu statku do portu macierzystego.

Od pojawienia się telegrafu armator, dysponujący teraz siecią międzynarodowych powiązań i kontaktów z giełdami towarowymi, miał znacznie większe możliwości znalezienia ładunku niż kapitan na statku. Mógł także, dysponując większa ilością czasu, wynegocjować wyższe stawki frachtowe, tym bardziej, że zatrudnił do tego celu doświadczonego kupca-negocjatora, zwykle agenta giełdowego, w następstwie czego w przedsiębiorstwie armatorskim pojawił się dział frachtowania.

Armator zastrzegł sobie nadzór nad systemem mustrowania załogi zakładając, że statek stał się zbyt kapitałochłonną lokatą kapitału, by obsługiwała go niedoświadczona, i bez referencji, załoga. W przedsiębiorstwie armatorskim pojawiło się stanowisko kierownika/dyrektora do spraw osobowych. Eksploatacja parowców i konieczność organizacji napraw i przeglądów maszyny oraz samego statku spowodowały także powstanie w siedzibie armatora działu technicznego nadzorującego z lądu system przeglądów, napraw statków a także nadzorującego pracę i zatrudnienie mechaników.

Kapitan zobowiązany został przez armatora do ciągłego meldowania o swoim położeniu i określania przewidywanego terminu wpłynięcia statku do portu. Otrzymywał z lądu instrukcje odnośnie do ilości zabukowanego ładunku i jego przeznaczenia, szacowanego terminu wyjścia z portu oraz zawinięcia do portu przeznaczenia, otrzymywał także instrukcję w jakim porcie i ile ma wziąć bunkru, kto jest jego agentem klarującym i przy jakim nabrzeżu ma zacumować.

Kapitanowi pozostawiono najważniejsze kompetencje. Mimo że przestał być decydentem, a stał się posłusznym wykonawcą - z punktu widzenia bezpieczeństwa statku i załogi został zobowiązany do:

- prowadzenia rzetelnej i dokładnej nawigacji,

- $\quad$ nadzoru wraz z agentem klarującym terminowości za- i wyładunku,

- dbałości nad użytkowaniem i bezpieczeństwem oraz konserwacją sprzętu pokładowego i statku, 
- dbałości wspólnie z ochmistrzem o dobrobyt socjalny załogi,

- dbałości wspólnie z I mechanikiem o maszynę i urządzenia techniczne,

- dbałości wspólnie z radiooficerem o łączność ze światem a szczególnie z armatorem.

Zmiany te, czyli podział funkcji pomiędzy przedsiębiorstwem armatorskim na ladzie a jego częścią, czyli statkiem, które wykształciły się w latach 1910-1920 trwają z niewielkimi korektami, do dziś.

Dzięki telegrafowi zarząd firmy armatorskiej osobiście i na własną odpowiedzialność zaczął w pełni dysponować statkiem, kontrolować na bieżąco jego ruchem, reagować bezpośrednio na wszelkie wydarzenia na morzu. Stało się opłacalne tworzenie firm armatorskich, ich łączenie w wielkie, silne finansowo towarzystwa zdolne przetrzymać okresy niekorzystnych stawek frachtowych, zwłaszcza, że żegluga stała się niezwykle kapitałochłonnym działem gospodarki.

Rozwój handlu i przyspieszony wzrost taboru morskiego oraz liczby przewoźników, czyli przedsiębiorstw armatorskich spowodował wzrost liczby szkół morskich. Ich kadrę stanowili kapitanowie żaglowców a także parowców, którzy zeszli na ląd, ponieważ nie mogli pogodzić się z ograniczeniem ich kompetencji, inżynierowie mechanicy oraz radiooficerowie. Uczelnie zaczęły przygotowywać nową kadrę oficerów w systemie dziennym, jednak egzaminy na patent oficerski odbywały się indywidualnie, po odbyciu odpowiedniej praktyki morskiej.

Na uczelniach handlowych zaczęto przygotowywać kadrę lądową dla przedsiębiorstw armatorskich. Lata dwudzieste XX wieku to czas powstawania na tych uczelniach podręczników z dziedziny ekonomiki transportu morskiego. Uczono prawa morskiego, ekonomiki transportu, ubezpieczeń w transporcie morskim, funkcjonowania giełdy frachtowej, a w ramach finansów - zasad kredytowania rozwoju przedsiębiorstwa armatorskiego.

W roku 1910 wszedł do eksploatacji pierwszy tankowiec, a więc statek całkowicie różny od dotychczas eksploatowanych. Towarzystwa naftowe starały się zainteresować przewozami ropy firmy armatorskie, jednak oferowały zbyt niskie stawki frachtowe orientując się według stawek obowiązujących na rynku w danej relacji przewozowej, nie biorąc pod uwagę faktu pustych przebiegów balastowych oraz faktu wzrostu niebezpieczeństwa pracy na tankowcu a także bardzo krótkiego czasu pobytu statku w porcie. Czynniki te zadecydowały, że załogi nie chciały mustrować na tankowiec a jeśli tak, to żądając parokrotnie wyższej płacy niż na innych statkach. W ten sposób zaczęły powstawać floty koncernowe, należące do towarzystw naftowych. Z biegiem czasu armatorzy, za odpowiednio wysoki fracht, zaczęli podejmować się przewozów ropy i eksploatacji tankowców, jednak robili to ze względu na bezpieczeństwo ekonomiczne firmy na bazie długoletnich czarterów na czas.

Wejście do eksploatacji tankowców miało ogromny wpływ na porty morskie i ich wydajność.

Armatorzy obserwując bardzo krótki czas załadunku lub wyładunku tankowców (z wykorzystaniem pomp), uświadomili sobie, że statek stojący w porcie nie zarabia, a jedynie tworzy koszty. Radykalnie wzrosły wymagania odnośnie do uzbrojenia nabrzeży w sprzęt przeładunkowy. Rozpoczęto więc na masową skalę dozbrajanie portów, bowiem armatorzy preferowali tylko te, które oferowały najkrótszy czas związany z za- i wyładunkiem.

Następny, trzeci etap rozwoju żeglugi to lata od 1955 roku, czyli powstania w przedsiębiorstwach działów inwestycji taborowych, gdzie zaczęto, współpracując ze stoczniami, projektować i ustalać parametry techniczne nowego taboru. Był to także wynik badań naukowych jakie podejmowali ówcześni eksperci z dziedziny transportu morskiego a dotyczących dzielenia się 
rynku frachtowego i powstawania cząstkowych rynków. Armatorzy przez budowę wyspecjalizowanego taboru widzieli szansę na opanowanie tych rynków i uzyskanie wyższych frachtów. Skorzystali też z doświadczeń związanych z przewozem ropy tankowcami. Na rynkach przewozowych obok konwencjonalnych trampów z międzypokładami, przeznaczonych do przewozu różnorakich ładunków, pojawiły się masowce, i tonaż Oil/Bulk/Ore.

Obok konwencjonalnych tankowców do przewozu ropy pojawił się tabor VLCC, chemikaliowców oraz gazowców, czyli LNP, LNG, a także tabor do przewozu produktów ropy naftowejbenzynowce czy asfaltowce.

Tabor liniowy zmienił się przez wyodrębnienie się kontenerowców, paletowców, Ro-Ro, systemu LASH oraz promów morskich. Żegluga pasażerska, która na dalekich trasach przegrała konkurencję z lotnictwem przeszła do obsługi turystyki - powstał crusing.

Proces ten trwał przez około 10 lat i spowodował ogromne zmiany w systemie eksploatacji taboru oraz przez koncentrację i centralizację kapitału doprowadził do zawierania pooli i powstawania konsorcjów, zwłaszcza w żegludze nieregularnej, rozwoju flot koncernowych i przedsiębiorstw operatorów, czyli podejmujących się eksploatacji wyczarterowanego taboru.

Na lata 60., 70., 80. XX wieku przypadła inna rewolucja związana z informatyzacją w przedsiębiorstwie armatorskim, wprowadzenia łączności mailowej dzięki połączeniom satelitarnym ze statkiem a także rewolucja związana z systemem GPS i włączeniem go do nawigacji, co pozwalało nie tylko na precyzyjne prowadzenie statku, ale także na dokładne określenie pozycji statku przez armatora i dalszą kontrolę nad jednostką. Jeśli chodzi o sam statek morski, aby zminimalizować koszty osobowe zmniejszano liczebność załogi, zmniejszono obsady wacht, zlikwidowano stanowisko ochmistrza, łącząc jego zadania z zadaniami kucharza, wprowadzano jednoosobowe wachty w maszynowni. Pozostawiono stanowiska radiooficera i elektryka-informatyka odpowiedzialnego za urządzenia elektroniczne na statku.

Lata 60., 70., 80. i 90. XX wieku to czas kiedy do przedsiębiorstw armatorskich, agencji morskiej i portów trafiali wyuczeni przez pracowników Zakładu Ekonomiki Transportu Morskiego i Śródlądowego a wypromowani przez prof. dr hab. Gronowskiego magistranci i doktoranci. Jak dawali sobie radę z tymi zmianami - czy byli do nich przygotowani? Patrząc z perspektywy czasu na rozwój firm, którymi zarządzali ich pracę należy ocenić pozytywnie.

Każdy wykładowca czy też promotor, ucząc swych studentów i wiedząc, że trafią do różnych przedsiębiorstw musi sobie odpowiedzieć na wile pytań, z których najważniejszym jest czy moi studenci mają wystarczającą wiedzę i czy ta wiedza pozwoli na analizę sytuacji w firmie i postawienie właściwej diagnozy co dalej pozwoli im przystosować się do częstych zmian w otoczeniu zarówno wewnątrz, jak i na zewnątrz przedsiębiorstwa, czy też instytucji, do której trafią. Następne pytanie to - czy moi studenci potrafią nie tylko zaakceptować zmiany wprowadzane przez innych, ale i samemu dokonywać takowych, modernizując działania instytucji, do których trafiają i którymi w końcu będą kierować, czy też wybiorą rolę biernego wykonawcy zamiast czynnego uczestnika zmian.

Zastanawiając się nad tym wypadałoby porównać programy nauczania na polskich uczelniach kształcących ekonomistów z dziedziny transportu morskiego oraz programy zagranicznych uczelni. Istotną także okazuje się motywacja i podejście samego studenta do procesu przyswajania wiedzy. 
Jeśli chodzi o programy nauczania, to należy stwierdzić znaczące różnice wynikające z odmienności systemów ekonomicznych trwające do końca lat 80. XX wieku, kiedy to panujący w Polsce ustrój socjalistyczny oparty na centralnym planowaniu pozbawiał kierownictwo przedsiębiorstw możliwości podejmowania decyzji strategicznych, zastrzeżonych wyłącznie dla centrum planistycznego. Programy nauczania księgowości jako systemu informacji dla zarządów przedsiębiorstw, a także finansów przedsiębiorstw czy też finansów międzynarodowych zostały ograniczone. Studenci w Polsce nie uczyli się nic, albo jeśli tak to niewystarczająco o zasadach funkcjonowania giełd frachtowych, zasadach prognozowania trendów zmian frachtów, podziału rynków frachtowych. Jeśli chodzi o teorię organizacji i zarządzania, a szczególnie takie jej dziedziny, jak budowa struktur organizacyjnych, rozwój struktur hybrydowych, zależności pomiędzy a strategią przedsiębiorstw a ich strukturami, rodzaje strategii przedsiębiorstw, to studenci w Polsce niewiele wiedzieli, bowiem nauki związane z zarządzaniem przedsiębiorstwem w latach 50. XX wieku uznano za nauki kapitalistyczne i ich zakazano, po to aby w latach sześćdziesiątych, po odblokowaniu zakazów, ograniczać ich rolę. Rozwój teorii organizacji i zarządzania nastąpił dopiero w latach 70. XX wieku.

Inne różnice w programach nauczania wynikały ze ściślejszej współpracy uczelni z przedsiębiorstwami armatorskimi w krajach gospodarki rynkowej. Przedsiębiorstwa te musiały generować zyski, których wypracowanie gwarantowało dalszy ich rozwój, dlatego zamawiały na uczelniach opracowania dotyczące możliwości działania w ramach rozwijających się rynkach cząstkowych, przy okazji dofinansowując uczelnie. Korzystając z wiedzy dotychczasowych absolwentów i jednocześnie dostrzegając braki w ich edukacji, zarządy przedsiębiorstw wspólnie z władzami uczelni na bieżąco, dzięki dodatkowym wykładom fakultatywnym czy też seminariom prowadzonym przez praktyków, zwykle metodą "case study” uzupełniały te braki.

Starano się także pokazać studentom w jaki sposób zdobyta wiedza może się przydać, np. w Wyższej Szkole Handlowej w Bergen popularnością cieszyło się seminariom „Jak stworzyć własne przedsiębiorstwo armatorskie", stanowiące połączenie wiedzy z zakresu funkcjonowania rynków frachtowych, finansów (szczególnie zasad kredytowania działalności) oraz księgowości, tzn. czytania zarówno kąt analitycznych jak i samego bilansu przedsiębiorstwa. Robiono to na przykładach funkcjonujących już przedsiębiorstw. Prowadzono także seminaria dotyczące działania i strategii korporacji żeglugowych i sposobów uzyskiwania efektów synergii podczas ekspansji a także zasad dywersyfikacji działalności.

W tym samym czasie w Polsce, od momentu powstania przedsiębiorstw armatorskich aż do końca lat 80 . XX wieku ze strony polskich armatorów nie pojawiało się takie zapotrzebowanie. Pracownicy uczelni (w tym czasie Politechniki Szczecińskiej), to jest pracownicy Katedry Ekonomiki Transportu Morskiego i Śródlądowego prowadzonej przez prof. dr hab. Franciszka Gronowskiego, mimo wszystko, obserwując trendy rozwoju żeglugi światowej, powstawanie coraz to nowych cząstkowych rynków frachtowych i przystosowywanie się do nich tonażu, starali się przekazać to swoim studentom. Prowadzono także przez ekspertów-praktyków wykłady fakultatywne dotyczące organizacji przedsiębiorstwa armatorskiego czy też spedycji w transporcie morskim, dzięki czemu zetknięcie się absolwentów z międzynarodowymi rynkami frachtowymi w pracy przedsiębiorstwa armatorskiego nie stanowiło szoku.

Nieco inaczej wyglądał system kalkulacji zarówno wstępnej, jak i wynikowej kosztów podróży statku, jako że był zakłócony systemem zarówno dziwnych kursów walut, jak i dopłat de- 
wizowych, wskutek czego nigdy nie było wiadomo czy naprawdę dana podróż statku przynosi zysk, a w konsekwencji - czy cały podpisany kontrakt na przewozy, np. wielu milionów ton rudy żelaza, czy węgla - jest korzystny. Sygnały odnośnie do braku możliwości właściwej kalkulacji frachtów nie martwiły jednak centrum planistycznego, bowiem tabor morski w zamierzeniach centrum stanowił nie tyle środek do wypracowywania zysku, co zabezpieczenie potrzeb przewozowych polskiego handlu zagranicznego, stąd też naciski na zachowanie w transakcjach handlowych własnej gestii transportowej. Myślenie takie było powrotem do teorii z pierwszego okresu rozwoju żeglugi, teorii kupca-właściciela statku i ładunku, który kalkuluje różnicę w cenie towaru w miejscu załadunku i wyładunku i liczy czy to mu się opłaca, z tym, że taka kalkulacja opłacalności została zakłócona przez nierealistyczny system kursów walut i dopłat dewizowych do eksportu towarów.

Następną rewolucją, która czekała na absolwentów Wydziału Ekonomiki Transportu było wprowadzenie informatyki do przedsiębiorstw armatorskich. Połowa lat sześćdziesiątych to czas intensywnej informatyzacji przedsiębiorstw armatorskich w krajach gospodarki rynkowej. W pierwszej fazie rozwoju korporacje armatorskie, tak jak i inne, w informatyzacji widziały rozwiązanie problemów sprawnego zarządzania. Dzięki odpowiednim programom księgowym z odpowiednio dużą, w stosunku do potrzeb, liczbą kont analitycznych i niespotykaną do tej pory sprawnością i szybkością obliczeń, zarząd przedsiębiorstwa mógł w sposób szybki i sprawny zdiagnozować sytuację na poszczególnych rynkach oraz podjąć właściwą decyzję. Poszczególne działy mogły prowadzić zgodnie ze wskazaniami sprawną dyspozycję posiadanym taborem.

Na przełomie lat 60. i 70. zaczęto konstruować modele ekonometryczne rozpisywane następnie na programy informatyczne wspomagające procesy decyzyjne w przedsiębiorstwie armatorskim w tym programy kalkulacji stawek frachtowych na różnorodnych rynkach cząstkowych. Informatyzacja w przedsiębiorstwie stała się koniecznym standardem.

W tym samym czasie w Polskiej Żegludze Morskiej i Polskich Liniach Oceanicznych obliczenia w księgowości dokonywano za pomocą „małej mechanizacji” a zliczenia do kalkulacji stawek frachtowych na napędzanych ręcznie maszynach. Nadal funkcjonowały hale maszyn księgujących oraz hale maszyn do przepisywania zleconych tekstów. Kierownictwa firm państwowych, wyznaczane w sposób polityczny nie odczuwały presji konkurencji, tak jak zarządy firm funkcjonujących w gospodarce rynkowej. Zawsze liczyły na pomoc państwa w sytuacji trudnej, a także na dodatkowe dofinansowania przy zakupie nowego taboru. Badania w celu ekspansji na nowe rynki frachtowe wydawały im się zbędne. Liczono zawsze na ładunki polskiego handlu zagranicznego.

Na Uczelniach, w tym na Wydziale Inżynieryjno-Ekonomicznym, już w połowie lat sześćdziesiątych pojawiły się polskie Odry, uczono choć w niewielkim zakresie informatyki, natomiast w przedsiębiorstwach nie odczuwano potrzeby innowacji. Informatyka naprawdę dotarła do polskich armatorów dopiero w latach 80 . XX wieku. Zaistniała wtedy potrzeba poznania podstaw informatyki i obsługi komputera metodą samokształcenia przez tych studentów, którzy ukończyli studia na przełomie lat 50., 60. i 70. XX wieku. W ten sposób dokonywała się pierwsza selekcja dawnych studentów Wydziału Inżynieryjno-Ekonomicznego - wtedy już kadry kierowniczej - na tych, którzy chcieli się uczyć i tych, którzy obawiając się nowości woleli zmienić pracę i przejść do instytucji, gdzie nie było takiego wymogu. Należy stwierdzić, że od- 
padli nieliczni a większość zmotywowana koniecznością pozostania w zawodzie przeszła ten etap zwycięsko. Stało się to tym łatwiej, że grupy studenckie na kierunku ekonomiki transportu morskiego były nieliczne, studenci należeli do najlepszych a przez pięć semestrów mieli bezpośredni i częsty kontakt z Profesorem Franciszkiem Gronowskim i pracownikami katedry, co pozwalało na utrzymanie stosunku uczeń-mistrz i stanowiło dodatkową motywację do nauki a także spowodowało, że zostali wdrożeni do solidnej pracy, logicznego myślenia i rzeczowego podejścia do rozwiązywania pojawiających się problemów. Łączyło się z tym zrozumienie konieczności ciągłej aktualizacji swojej wiedzy, po to aby sprostać ciągłym zmianom w otoczeniu przedsiębiorstwa. Absolwenci z lat osiemdziesiątych i późniejszych, uczący się informatyki zarówno w liceum, jak i na uczelni nie mieli już tego problemu.

Drugim, jeszcze większym wezwaniem była zmiana ustroju i przejście do gospodarki wolnorynkowej, które dokonało się w 1989 roku. Zmieniło się wtedy gwałtownie podejście państwa do przedsiębiorstwa oraz misja w funkcjonowaniu przedsiębiorstwa, gdzie głównym celem stało się kreowanie zysku na takim poziomie, aby zagwarantować nie tylko odtworzenie kapitału, ale jego rozwój. Zaspokojenie potrzeb polskiego handlu zagranicznego, mimo że było dla wszystkich niezwykle istotne, zeszło na drugi plan.

W przedsiębiorstwach przyjęto inne niż dotychczas formy organizacji kapitału, czyli formy spółek z ograniczoną odpowiedzialnością lub spółek akcyjnych. Wprowadzano konsekwentnie zmiany w systemie księgowości przez zwiększenie liczby kąt analitycznych.

Jeśli chodzi o finanse, to po ustaniu gwarancji bankowych ze strony Państwa zajęto się systemem finansowania inwestycji taborowych poprzez poszukiwanie takich wykonawców, którzy gwarantowali dostęp do nisko oprocentowanych i długoterminowych kredytów. Zmieniło się też podejście do rynku, poszukiwano bowiem ładunków o odpowiedniej wysokości stawek frachtowych. Rozpoczęto badania cząstkowych rynków frachtowych. W końcu też zrozumiano, że przedsiębiorstwo stanowi system, w którym odpowiednie powiązanie wiedzy z różnych dziedzin przynosi sukces. Nadal jednak słabą stroną armatorów polskich był marketing ładunków a w szczególności marketing w formie agresywnej. Wiązało się to częściowo z tym, że polskie organa kontroli skarbowej nie zawsze (w przeciwieństwie do organów skarbowych innych państw) dopuszczały do agresywnych form marketingu.

Zarządy przedsiębiorstw przekonały się, iż system gospodarki rynkowej nie toleruje strat w bilansach przedsiębiorstw i mimo że nadal, tak jak w poprzednim systemie, w spółkach z przewagą kapitału państwa występowały tendencje do obsadzania stanowisk „swoimi ludźmi”, bez kompetencji, co w konsekwencji przynosiło przedsiębiorstwom, którymi kierowali straty.

W podsumowaniu należy podkreślić, że przed każdym pokoleniem, które ukończyło studia na Wydziale Transportu, w katedrze Ekonomiki Transportu Morskiego i Śródlądowego stawały inne problemy. Absolwenci z lat 50. i 60. oraz 70. XX wieku trafiali do przedsiębiorstw funkcjonujących w gospodarce planowej, gdzie priorytetem były przewozy polskiego handlu zagranicznego, natomiast przewozy cross-trade były dodatkiem. Absolwenci ci, kierując przedsiębiorstwem czy też jego działami, zmuszeni byli do liczenia frachtów dziwnymi kursami walut i posługiwania się systemem dopłat eksportowych utrudniających prawdziwą i rzetelną ich kalkulację.

W latach 70. i 80. uczelnię kończyło więcej absolwentów niż w latach poprzednich i kształcono ich już bardziej jako ekspertów z dziedziny transportu morskiego. Musieli jednak podo- 
łać zmianom i przystosować przedsiębiorstwa, do których trafiali do rewolucji informatycznej, a później, wraz z młodszymi kolegami, przystosować przedsiębiorstwa do funkcjonowania w gospodarce rynkowej. Absolwenci z lat 90., zaczynający pracę w nowych warunkach gospodarki rynkowej, wraz ze starszymi kolegami podjęli zwycięską walkę, konkurując z innymi przedsiębiorstwami na światowych rynkach. Aby przetrwać, podejmowali odważne decyzje, np. przeflagowania taboru, żeby nie zostać zniszczonym przez system podatkowy własnego państwa.

Przez wszystkie te lata uczelnia i pracownicy katedry Transportu Morskiego i Śródlądowego pod kierunkiem Profesora dr hab. Franciszka Gronowskiego starali się jak najlepiej przygotować studentów do realizacji przyszłych zadań w gospodarce morskiej - ich późniejsze, indywidualne kariery należały już do samych absolwentów. Oceniając pracę Profesora Franciszka Gronowskiego i pracowników katedry, według kondycji i rozwoju firm oraz instytucji, do których trafiali i którymi zarządzali absolwenci studiów magisterskich i doktoranci przez niego wypromowani, należy w sposób jednoznaczny użyć angielskiego zwrotu well done. 